IRSTI $30.19 .25 ; 30.19 .29$

https://doi.org/10.26577/JMMCS.2020.v105.i1.09

\author{
${ }^{1}$ E.K. Abdyldaev ${ }^{\text {iD }},{ }^{2}$ M.O. Nogaibayeva \\ ${ }^{1}$ Dr. Sci. (Tech.), Prof., E-mail: abderkinbek@mail.ru \\ ${ }^{2}$ Senior lecturer, E-mail: mnogaibayeva@gmail.com \\ Al-Farabi Kazakh National University, Almaty, Kazakhstan
}

\title{
MATHEMATICAL MODELING OF THE PROBLEM OF COMPRESSION OF A ROCK SAMPLE WITH FRICTION AT THE END
}

\begin{abstract}
Analytical solutions of the problem of the stress-strain state of the environment around the workings with non-uniform compression in the elastic-plastic formulation, with account for transboundary deformation are few. Some solutions of the problem under the conditions of Tresk and Coulomb plasticity are obtained.

In these solutions, there are simplifying assumptions that the area of inelastic deformations cover the entire contour of the mine, the angle of internal friction is zero, etc. The features of the postlimit deformation of rock masses near underground mines consist on the formation of destruction zones around the mine workings, zones of plastic and elastic deformation, covering the part of contour or the entire contour depending on the boundary conditions and contour profiles, and a given law of the state of the environment. The mathematical description of the process of formation of inelastic deformations areas near the workings and obtaining a solution by the analytical method is rather difficult. Due to the lack of knowledge of this problem to date, it is advisable to use numerical methods of mathematics and mechanics using modern information technology and technology. The article presents mathematical models and results of solving a geomechanical problem based on information technology and the finite element method. The developed procedures and programs allow solving with the help of modern computers a wide class of mining tasks in which it is required to determine the stress-strain state of the rock mass weakened by mine workings in different mining and geological conditions.
\end{abstract}

Key words: geomechanical tasks, field structures, mathematical models, array heterogeneity, rock properties, rock samples.

\author{
1Э.К. Абдылдаев, ${ }^{2}$ М.О. Ногайбаева

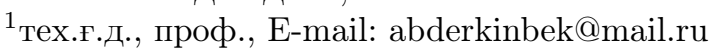 \\ 2 аға оқытушы, E-mail: mnogaibayeva@gmail.com \\ әл-Фараби атындағы Қазақ ұлттқ университеті, Алматы қ, Қазақстан \\ Бүйір шетінде үйкелісі бар тау жыныстарының үлгілерін сығу есебін \\ математикалық модельдеу
}

Шекарадан тыс деформацияларды ескеретін бірқалыпты емес сығылу кезіндегі кен қазбаларының айналасындағы серпімді-пластикалық қойылымдағы ортаның кернеулідеформацияланған күйі туралы есептердің аналитикалық шешімдері өте аз. Треска мен Кулонның пластикалық жағдайындағы есептің кейбір шешімдері алынды. Бұл шешімдерде, серпімді емес деформация аймағы өнімнің барлық жиегін қамтиды, ішкі үйкеліс бұрышы нөлге тең және т. б. секілді қарапайым болжамдар бар. Тау-кен массивтерінің жер асты қазбаларына жақын шекарадан тыс деформациялануының ерекшеліктері мынадай: тау-кен қазбаларының айналасында қирау аймақтары, жиектің шекаралық шарты мен профиліне, сондай-ақ орта жағдайының берілген заңына байланысты жиектің бөлігін толық жиекті қамтитын пластикалық және серпімді деформация аймақтары пайда болады. өнімдерге жақын серпімсіз деформация ортасының құрылу процессінің математикалық сипаты мен аналитикалық әдіспен шешімін табу өте күрделі болып табылады. 
Қазіргі таңда осы проблеманың аз зерттелуіне байланысты қазіргі заманауи ақпараттық техника мен технологияны пайдалана отырып, математика мен механиканың сандық әдістерін пайдаланған жөн. Мақалада ақпараттық технология және соңғы элементтер әдісі негізінде геомеханикалық есептерді шешудің математикалық модельдері мен нәтижелері келтірілген. Әзірленген процедура мен программалар қазіргі заманауи компьютерлердің көмегімен әртүрлі тау-кен техникалық және тау-кен геологиялық жағдайларда қазбалармен әлсіреген тау-кен массивінің кернеулі-деформацияланған күйін анықтауды талап ететін таукен өндірісі есептерінің кең класын шешуге мүмкіндік береді.

Түйін сөздер: геомеханикалық есептер, кенорнының құрылымы, математикалық модельдер, массивтің біркелкіеместігі, тау жыныстарының қасиеттері, тау жыныстарының

\author{
1Э.К. Абдылдаев, ${ }^{2}$ М.О. Ногайбаева

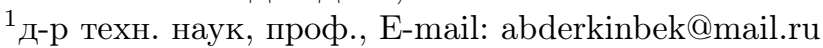 \\ ${ }^{2}$ старший преподаватель, E-mail: mnogaibayeva@gmail.com \\ Казахский национальный университет им. аль-Фараби, г. Алматы, Казахстан \\ Математическое моделирование задачи сжатия образца горных пород \\ с трением на торцах
}

\begin{abstract}
Аналитические решения задачи о напряженно-деформированном состоянии среды вокруг выработок при неравномерном сжатии в упруго-пластической постановке с учетом запредельного деформирования малочисленны. Получены некоторые решения задачи в условиях пластичности Треска и Кулона. В этих решениях имеются упрощающее предположения, что область неупругих деформаций охватывают весь контур выработки, угол внутреннего трения равен нулю и др. Особенности запредельного деформирования породных массивов вблизи подземных выработок заключается в том, что вокруг горных выработок образуются зоны разрушения, зоны пластических и упругих деформаций, охватывающих часть контура или весь контур в зависимости от граничных условий и профилей контура, а также заданного закона состояния среды. Математическое описание процесса формирование областей неупругих деформаций вблизи выработок и получения решения аналитическим методом представляется достаточно сложным. В связи с мало изученности данной проблемы на сегодняшний день, целесообразно использовать численные методы математики и механики с использованием современной информационной техники и технологии. В статье приведены математические модели и результаты решения геомеханической задачи на основе информационной технологии и метода конечных элементов. Разработанные процедуры и программы позволяют решать с помощью современных компьютеров широкий класс задач горного производства, в которых требуется определять напряженно-деформированное состояние породного массива, ослабленного выработками в разных горнотехнических и горногеологических условиях.
\end{abstract}

Ключевые слова: геомеханические задачи, структуры месторождения, математические модели, неоднородность массива, свойства пород, образцы горных пород.

\title{
1 Introduction
}

In the national economy of the Republic of Kazakhstan, the mining industries occupy one of the most important places in their role in social production, economic importance and social factors. In this regard, in order to create effective and reliable designs of mines and quarries, the development of an environmental monitoring system for the environment in the field of mining must be comprehensive, combining basic and applied sciences. In the Republic, one of the priorities is to increase the rate of extraction and supply of natural resources to the markets in order to use the current high global demand in the interests of the country. The competitiveness of mining enterprises is mainly ensured with large volumes of mineral extraction. Their high-performance work is achieved on the basis of introducing into practice 
the results of scientific research to create new and improve existing technological schemes with the inclusion of cyclical and continuous technology, rational equipment, full expansion of the field of application of advanced technological solutions, as well as the use of advanced forms of organization and management of mass mining works.

The rapid development of information technology is currently placing new demands on traditional, well-established areas of knowledge, one of which is geomechanics and the development of subsoil. In connection with the depletion of mineral resources located at accessible depths, the main direction of development of the mining industry will be the further development and improvement of methods and methods of mining with involvement in exploitation of fields with complex mining and geological conditions, great depth of development and long service life of pit walls and underground workings. The modern level of development of the mathematical apparatus for solving problems of geomechanics and computing technology allows us to automate the design of workings, take into account all the details of the array structure, achieve greater reliability of design solutions that ensure minimal amounts of overburden work, safe working conditions, and rational use of the subsurface and land resources which becomes relevant in a market economy.

\section{Review of literature}

At the present stage of development of information technology, the most popular computational methods for assessing the stress-strain state of a rock massif and various structures are the methods of finite elements [1-11] and boundary elements [12-14]. As is well known, the boundary element method (MGE) is well suited to stress concentration problems or to infinite regions, and the finite element method (FEM) provides a cost saving procedure in many three-dimensional problems for finite regions. The simplicity of the mathematical theory, the ease of generalization in solving the problem and the applicability to physically and geometrically non-linear problems make the FEM more attractive, while for the MGE this is still the subject of research. The finite element method (FEM) is a synthesis of the latest achievements of continuum mechanics and numerical methods of mathematics. It has received extremely wide application in various fields of physics and technology, mainly in the analysis of the stress-strain state. Fundamentally new FEM opens in the mechanics of rocks and soils. Before its appearance, the solution of geotechnical problems was possible only in an elastic formulation, or by means of limiting equilibrium - and then under fairly simple boundary conditions. Most of the elastic-plastic problems are not amenable to an analytical solution, as a result of which, in many cases, the loads on the soil are artificially limited to the elastic phase of deformation [15-25]. The current literature on FEM is extremely extensive and literally every entry into the scientific and technical libraries brings new information in this field.

\section{Objects and research methods}

Mining enterprises, unlike many other industrial facilities and structures (metallurgical, machine-building, chemical plants, etc.) are natural-technological complexes. The parameters and indicators of the economic efficiency of mining enterprises are determined for this 
level of technology mainly by natural factors (structure and size of deposits, terrain, hydrological conditions, etc.) and their permissible environmental impact. It should be noted that at the present stage of development of mining science it is the differentiation of mining science, the emergence of its new industries and divisions on the basis of its integration with related fields of science and technology. Search and scientific substantiation of the methods of rational and integrated use of the subsoil, ensure their comfortable working conditions and optimal state of the environment.

The latest stage in the development of mining science should be associated with the deployment of the scientific and technological revolution (STR). Scientific and technological revolution, as is known, has set new problems for humanity: environmental protection and depletion of mineral-fuel resources. These problems are particularly relevant for the mining industry and science, without deciding which, the further production use of mineral resources can become socially ineffective. It should be noted that in the areas of mining the geographical environment is sharply deteriorating, a method of open-cast mining causes great harm to it, an increase in the share of which is planned in the near future. The effectiveness of the method is already currently minus large inevitable costs of reclamation of disturbed land. Hence the formulation before science of a fundamental change in the technology of mining. This is especially true because modern technology does not allow developing deposits in the deep bowels of the earth, as well as with a low mineral content. Therefore, it is so important to develop fundamentally new methods and means of mining, to avoid the movement of masses of waste rock, to exclude the presence of a person under the ground, to dramatically increase labor productivity. This is a real task, as there is an internal training and maturity of mining science to enrich it with the latest achievements of the fundamental sciences, on which meringue a fundamental shift in the technical base of mining production can be achieved. In world practice, technical progress is primarily related to the orientation on the widespread use of self-propelled mining equipment: the development of self-propelled drilling, loading-hauling and transport equipment, self-propelled bucket loading-hauling machines (PDM) with both diesel and electric drive. The development of information and communication technologies, the widespread introduction of automation and remote control of mining machines and aggregates are priority areas for the improvement of underground technology. Differentiation of mining science on the basis of its integration with related fields of science and technology and at the same time is a synthesis of mining sciences into a single system of knowledge for finding methods for the rational and integrated use of the subsurface, providing comfortable working conditions and an optimal state of the natural environment. The goal of mining science is not only to describe, explain the conditions of means and methods of exploration for mining and primary processing of minerals, but mainly in finding ways to improve and change them to facilitate working conditions and increase production efficiency. Mining science today is a complex, developing complex of scientific disciplines. All processes and phenomena occurring during the exploration, mining and processing of minerals contain internal and external contradictions, the discovery, study and resolution of which is the main task of mining science.

The general trend of mathematization of sciences has not bypassed mining sciences, but today for solving most major mining problems there are not enough mathematical tools, because the task, for example, of developing fields is to create self-organizing multi-factor systems, and later on self-programming auto steps. At the present stage, the tasks arising, for example, in the development of mineral resources, can be quantitatively solved only in 
relation to certain, ideal deposits. Therefore, in order to impart practical significance to such "quantitative"decisions, the assumptions underlying the analysis should, in accordance with accepted values, be consistent with natural conditions [1-5].

\section{Mathematical media models}

In the process of formation in the massif of open or underground mine workings, the natural stress-strain state is disturbed. Zones of non-elastic deformations appear around the workings for various purposes. Of particular importance are the patterns of deformation of rocks beyond the limits of strength associated with loosening (irreversible increase in volume), weakening (decrease in resilience) and hardening. These patterns largely determine the nature of the stress-strain state of the rock mass near the workings, especially with the combined mining of mineral deposits by open and underground methods in mutual influence on each other [6-13].

We write Hooke's law for the conditions of plane strain $\left(\xi_{2}=0\right)$ in the following form:

$$
\begin{gathered}
\sigma_{1}=E_{\Pi}\left(\varepsilon_{1}+\nu_{\Pi} \varepsilon_{3}\right) /\left(1-\nu_{\Pi}^{2}\right), \\
\sigma_{3}=E_{\Pi}\left(\varepsilon_{3}+\nu_{\Pi} \varepsilon_{1}\right) /\left(1-\nu_{\Pi}^{2}\right)
\end{gathered}
$$

where $(\Pi), \nu_{\Pi}-$ are the "flat" analogs of the Young's modulus $E$ and the Pausson coefficient $\nu$, related to them by the relations: $\Pi=/\left(1-\nu^{2}\right), \nu_{\Pi}=\nu /(1-\nu)$.

Considering that the ultimate strength of the medium under consideration in the field of compression is described by the Coulomb criterion:

$$
\sigma_{1}=S+\sigma_{3} \operatorname{ctg} \delta
$$

where $S=2 c \operatorname{ctg}(\pi / 4-\varphi / 2)$ - is the uniaxial compression strength; $\operatorname{ctg} \delta=(1+\sin \varphi) /(1-$ $\sin \varphi) ; c, \varphi-$ grip and angle of internal friction.

In the field of tension, we supplement the criterion $\sigma_{3}=T, T$ is the tensile strength. After simple transformations, we obtain descriptions of the limits of strength through the main deformations - compression are considered positive:

$$
\begin{aligned}
& {\left[\left(E_{\Pi} \varepsilon_{1}-S\right)\left(1-\nu_{\Pi} \operatorname{ctg} \delta\right) /(\operatorname{ctg} \delta-\nu)-\nu_{\Pi} S\right] / E_{\Pi}-\varepsilon_{3}=0} \\
& T\left(1-\nu_{\Pi}^{2}\right) / E_{\Pi}-\nu_{\Pi} \varepsilon_{1}-\varepsilon_{3}=0
\end{aligned}
$$

In the coordinates $\varepsilon_{1}$ and $\varepsilon_{3}$ equations (3) and (4) have the form, respectively, of straight lines A'B' and D'A' (Fig. 1, a). Thus, in region 1 within the limits of circuit D'A'B', according to the known deformations $\varepsilon_{1}$ и $\varepsilon_{3}$ of stresses $\sigma_{1}$ and $\sigma_{3}$, can be found by formulas (1). Outside the contour of A'B'C', other equations of the connection of deformations and stresses act.

Let in the process of loading the deformed state of the element of the medium reached a certain point $\mathrm{E}$ on the border of the elastic zone (Fig. 1a). Consider the laws of further plastic deformation occurring at a constant minimum principal stress. An increase in the strain $\varepsilon_{1}$ (i.e., shortening of the element of the medium in the direction $\varepsilon_{1}$ ) is accompanied by a decrease in the strain $\varepsilon_{3}$ (expansion in the perpendicular direction). The full vector of plastic deformations $\varepsilon_{p}$ (E'F' in Fig. 1a) consists of two components: $\varepsilon_{1 p}$ и $\varepsilon_{3 p}$ and the interrelation of these components is determined by the adopted law of flow. 


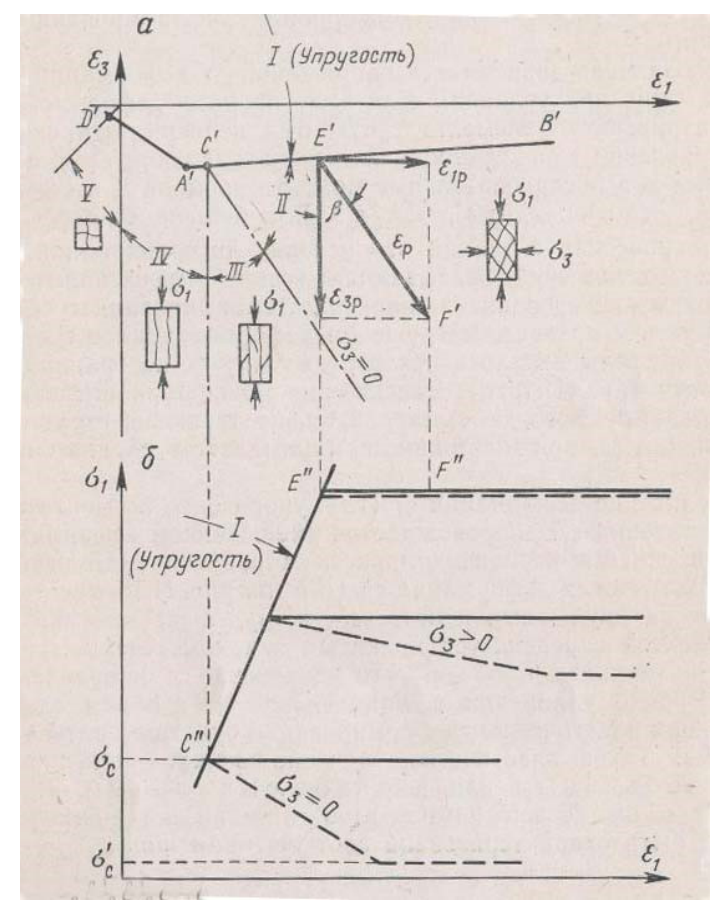

Figure 1: The law of the state of environment

If we accept $\varepsilon_{3 p}=-\varepsilon_{1 p}$ the shortening in the direction $\varepsilon_{1}$ will be equal to the elongation in the direction $\varepsilon_{3}$, and the volume of the element of the medium during plastic deformation will remain unchanged. Such plastic flow can be called equilibrium. In a more general case, the relationship between the components of plastic deformations can be characterized by the ratio of the form

$$
\varepsilon_{3 p}=-\operatorname{ctg} \beta \varepsilon_{1 p} .
$$

The angle $\beta$ in Fig. 1a determines the degree of loosening during plastic flow; the value $\operatorname{ctg} \beta$ can be called the dilation coefficient. When $\beta=\delta$, formula (5) corresponds to the principle of normality (the associated law of flow).

Moreover, if the deformations of the medium element $\varepsilon_{1}$ and $\varepsilon_{3}$ characterize the point $\mathrm{F}^{\prime}$ in Fig. 1a, then they can be represented as a sum of elastic and plastic components:

$$
\varepsilon_{1}=\varepsilon_{1_{e}}+\varepsilon_{1_{p}} ; \quad \varepsilon_{3}=\varepsilon_{3_{e}}+\varepsilon_{3_{p}} ;
$$

The elastic components $\varepsilon_{1_{e}}$ and $\varepsilon_{3_{e}}$ are the coordinates of the point E' and are determined from the elastic formulas (1) when the value $\sigma_{1}$ is substituted in them on the elastic boundary by the Coulomb formula (2). Substituting the values $\varepsilon_{1_{e}}$ and $\varepsilon_{3_{e}}$ and value $\varepsilon_{3_{p}}$ thus obtained from formula (5) into equations (6), we obtain a system of two equations, which having solved relatively $\sigma_{3}$ and $\varepsilon_{1_{p}}$, we find the voltage value $\sigma_{3}$ corresponding to this deformed state:

$$
\sigma_{3}=\left[E_{\Pi}\left(\varepsilon_{1}+\varepsilon_{3}\right)+S\left(\nu_{\Pi}-1\right)\right] /\left(1-\nu_{\Pi} \operatorname{ctg} \delta+\operatorname{ctg} \delta-\nu_{\Pi}\right) .
$$

To determine the value of $\sigma_{1}$, a family of connection graphs $\sigma_{1}$ and $\varepsilon_{1}$ should be specified for plastic deformation under the conditions $\sigma_{3}=$ const of Fig. $1 \mathrm{~b}$. If in the process of 
deformation resistance remains constant (perfect plasticity), then the graphs $\sigma_{1},-\varepsilon_{1}$ have the form of horizontal lines (solid lines in Fig. 1b), and the value $\varepsilon_{1}$ itself can be calculated from the previously determined value $\varepsilon_{3}$ using formula (2).

For rocks that are weakened in the process of transboundary deformation, for example, a family of graphs shown in Fig. 1b, by dashed lines, may be prompted. These graphs characterize the environment, the resistance of which in the process of plastic deformation decreases from the initial value, determined by formula (2), to the residual value

$$
\sigma_{1}=\min \left[\left(S+\sigma_{3} \operatorname{ctg} \delta\right),\left(S^{\prime}+\sigma \operatorname{ctg} \delta^{\prime}\right)\right],
$$

where $S^{\prime}$ and $\delta^{\prime}$ - residual strength characteristics $\left(S^{\prime}<S, \delta^{\prime}<\delta\right)$. The developed models are implemented in the form of numerical procedures for cases of plane strain in the deformation variant of the theory of plasticity based on the finite element method.

The main procedure of the finite element method considers the medium as elastic and reduces to solving a system of linear algebraic equations for unknown displacements

$$
\{u\}:\{F\}=[K]\{u\},
$$

where $[K]$ - the stiffness matrix of the system; $\{F\}$ - vector of nodal forces.

Since the study of the stress-strain state of the rock mass, taking into account transcendental deformability, is a non-linear problem, we have obtained new developments in the combined procedure for the general case, when the law of the state of the medium is given on the basis of the proposed model [14-16].

\section{Research results}

For the quantitative and qualitative assessment of the FEM solution using the above algorithm and the program developed on a $\mathrm{PC}$, the test problem of uniaxial compression of the sample with friction on the ends was solved. Due to the presence of two axes of symmetry, only a quarter of the area is considered (Fig. 2a). The axes of symmetry in the deformation process do not bend, and shear stresses are absent along the axes of symmetry. Three top nodes are set to move down equal to 0.018. Properties of the elements: $=100 P a, \nu=0.3$, $\nu=0, c=0.1 P a, \varphi=30^{\circ}$.

The problem is solved according to the developed program in two versions: in the first version, the state law obeys the associated flow law; in the second, a softening medium with a dilatation coefficient $\lambda=3$ is considered. In Fig. $2 \mathrm{~b}$ and $2 \mathrm{c}$ show the shapes of the deformed sample obtained as a result of calculation on a PC. To ensure equilibrium, these forces must be equal in magnitude and opposite in direction to given external forces, and in those nodes where external forces are not specified, they are equal to zero. In general, the sum of the nodal forces applied to the region in the $x$ and $y$ directions to ensure equilibrium must be zero. When solving each specific problem by checking, the fulfillment of the equilibrium condition was established.

To verify the fulfillment of the state law, we provided for printing not only the actual stresses found in the elements, but also the "theoretical" stresses calculated using the formulas for the adopted state law and the found strains. The quality of the solution can be estimated from the proximity of the values of the actual and theoretical voltages in Fig. $3 \mathrm{a}$ and $3 \mathrm{~b}$ 


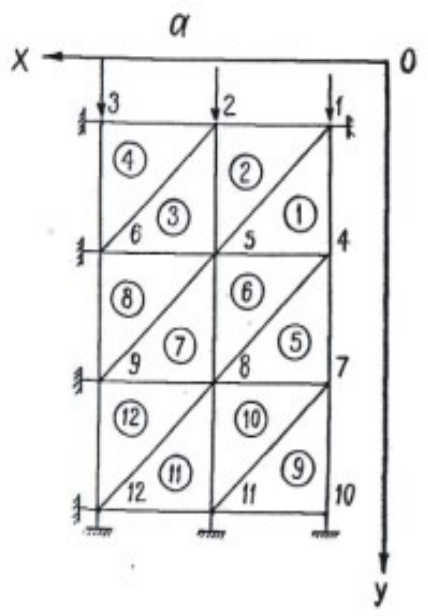

$\delta$

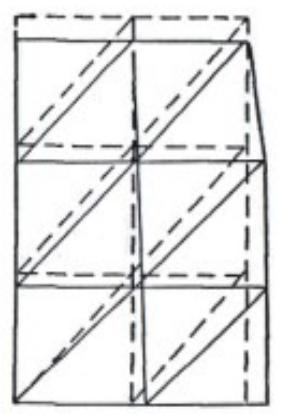

b

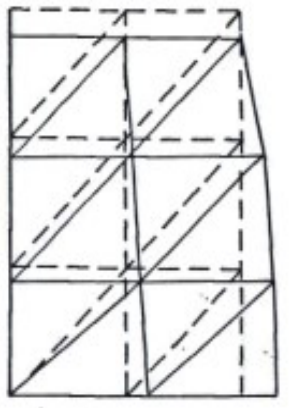

Figure 2: Test task: $a$-design scheme; $b$ - form of the sample after loading with the associated law of flow; $c$ - form sample in a softening medium

where the medium-strength datasheets and the actual stresses in the elements (points) are shown. In elements 2 and 4, the calculated deformations 1 and 3 are smaller than the limiting elastic deformation for a given stress 3 , therefore, they are in the elastic state. The remaining elements are in inelastic state. From Fig. 3a, b and from the calculation results it follows that the state law is satisfied for a given accuracy, the coaxiality of the main stresses and strains is maintained. Next, we check the fulfillment of the given law of flow, for example, on element No 10. The stresses in the element are equal: $\sigma_{1}=4.9, \sigma_{3}=0.39$, and the deformations: $\sigma_{1}=0.0070, \sigma_{3}=-0.0097$. Under plane deformation, according to Hooke's law, the elastic components of the deformations under such stresses are: $\varepsilon_{1}^{y}=0.0043, \varepsilon_{3}^{y}=$ -0.0016 . Accordingly, the plastic components are equal to:

$$
\varepsilon_{1}^{p}=\varepsilon_{1}-\varepsilon_{1}^{y}=0.0027 ; \quad \varepsilon_{3}^{p}=\varepsilon_{3}-\varepsilon_{3}^{y}=-0.0081
$$

As you can see, the ratio of plastic component strain

$$
\lambda=\left|\varepsilon_{3}^{p} / \varepsilon_{1}^{p}\right|=(0.0081 / 0.0021)=3
$$

isexactly equal to the given (associated) law of flow, characterized by $\lambda=3$. In the considered problems the found solution is unique. In principle, the solution of a plastic problem may not be the only one: for example, stretching an ideally plastic rod with a load equal to the yield strength of a material will not have a single solution. At the same time, stretching this rod to a given strain will have a single solution.

\section{Conclusion}

The developed mathematical models, procedures and programs allow us to solve with the help of modern computers a wide class of mining tasks in which it is required to determine the 

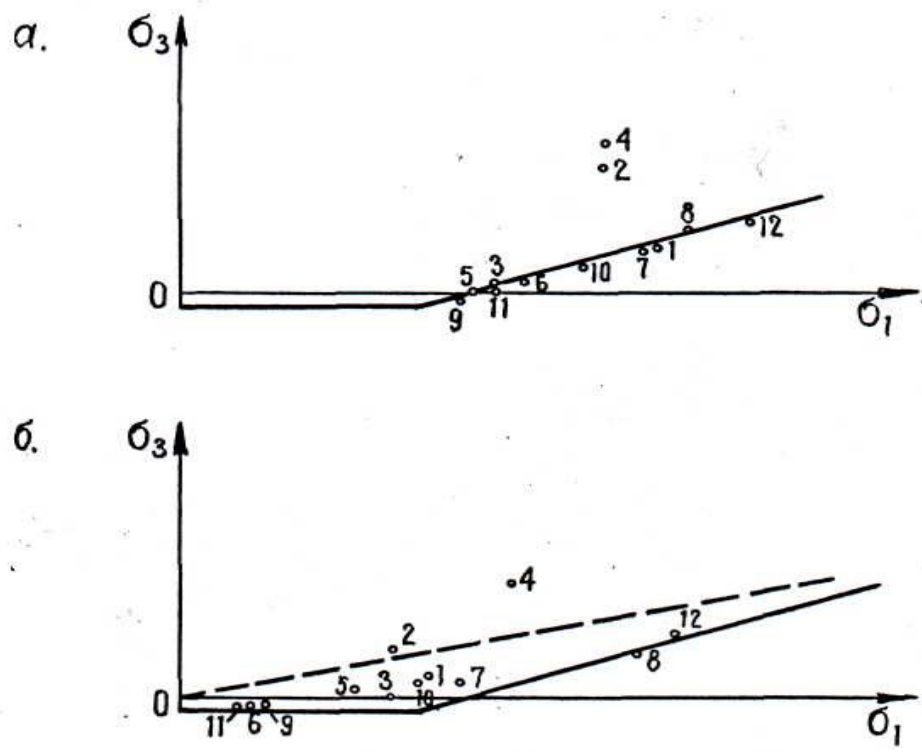

Figure 3: The stress state in the elements: a - with the associated flow law; b - in a softening environment

stress-strain state of the rock mass. The components of the natural stress field are represented as dependent on the geomechanical structures of the field, and are taken into account in the program using boundary conditions. In this case, the boundary conditions can be specified in the form of zero or nonzero nodal forces or displacements (or mixed conditions). Array heterogeneity is taken into account by model by introducing various strength and deformation characteristics $E, \nu, \gamma, c, \varphi$ (modulus of elasticity, Poisson's ratio, density, adhesion, and angle of internal friction). Surfaces of weakening and breaking in an array are imitated by layers of elements with corresponding lowered strength properties.

\section{References}

[1] Fadeev A.B. "Metod konechnyih elementov v geomehanike [The finite element method in geomechanics]", M.: Nedra (1987): 221

[2] Zenkevich O. "Metodyi konechnyih elementov v tehnike [Finite-element methods in engineering]" , M.: Mir (1975): 542.

[3] Erzhanov Z.S., Karimbaev T. "Metod konechnyih elementov v zadachah mehaniki gornyih porod [The finite element method in problems of rock mechanics]", Alma-Ata: Science (1975): 238.

[4] Bieniawski Z.T., Denkhaus H.G., Volger V.W. "Failure of fractured rock", Int. J. Rock Mech. Min. Sci. Vol. 6, No 3 (1969): 323-341.

[5] Bredy B.T. "Nonlinear mechanical behavior of the brittle rock", Int.J. Rock Mech. Min. Sci. Vol. 6, No 3 (1969): 211-225.

[6] Ghang G.Y., Duncan J.M. "Analysis of soil movement around a deep excavation", Proc. ASCE Vol. 96, No 5 (1970): 1655-1681.

[7] Goodman R.E., Toylor R.L., Brekke T.L. "A Model for the mechanics of jointed rock" , Proc ASCE Vol. 94, No SM3 (1968): 637-659.

[8] Tatsuoka F. "Fundamental Research for the Deformability of Sand by the Triaxle Apparatus" , Ph.D dissertation presented to Tokyo Univesity in Japanese (1972). 
[9] Turner M.J., Clough R.W., Martun H.C., Topp L.J. "Stiffness and deflection analysis of complex structures" , J. Aero. Sci. Vol. 23 (1965): 805-823.

[10] Zienkiewicz J.C., Valliopan S., King I.P. "Stress analysis of rock as a no tension material", Gtotechnique Vol. 18 (1968): $56-66$.

[11] Abdyldaev E.K. "Metod konechnyih elementov pri reshenii prikladnyih zadach [The finite element method for solving applied problems]", Almaty: Polygraphy-service (2011): 111.

[12] Kozhakhmetov K.Kh., Nurmambetova R.D., Ramatov K.S. "Pryamoy metod granichnyih integralov dlya resheniya zadach gornoy geomehaniki [The direct method of boundary integrals for solving problems of mining geomechanics]", Bulletin of the Academy of Sciences of Kazakhstan SSR No 9 (1987).

[13] Telles D. "Primenenie metoda granichnyih elementov dlya resheniya neuprugih zadach [Application of the boundary element method for solving inelastic problems]", M.: Stroiizdat (1987).

[14] Krauch S., Starfield A. "Metody granichnyih elementov v mehanike tverdogo tela [Methods of boundary elements in solid mechanics]", M.: Mir (1987).

[15] Kartashov, Yu. M., Matveev B.V., Mikheev G.V., Fadeev A.B. "Prochnost i deformiruemost gornyih porod [Strength and deformability of rocks]", M.: Nedra (1979): 269.

[16] Kazikaev D.M., Kozyrev A.A., Kasparyan E.V., Iosiv M.A. "Upravlenie geomehanicheskimi protsessami pri razrabotke mestorozhdeniy poleznyih iskopaemyih. Uchebnoe posobie [Management of geomechanical processes in the development of mineral deposits]", Tutorial. - M. Publishing House "Mining Book" (2016): 490.

[17] Rakishev B.R., Mashanov A.A., Abdyldaev E.K. "Struktura massiva i deformiruemost gornyih porod [The massif structure and deformability of rocks]", Almaty (2011): 281.

[18] Abdyldaev E. K., Mashanov A. A. "Metodyi otsenki ustoychivosti sklonov: Monografiya [Methods for assessing the stability of slopes: Monograph]", Almaty (2013): 203.

[19] Moldoshev R.A., Abdyldaev Ch.E., Abdyldaev E.K. "Deformatsionnyie modeli, uchityivayuschie dilatansii i razuprochneniya gornyih porod [Deformation models that take into account dilatancy and rock softening]", Bulletin of the Kazakh National Technical University named after KI Satpayev. Almaty No 1 (95) (2013): 21-24

[20] Abdyldaev E.K, Abdim Farabi. "Metodika organizatsi i mobilnogo obucheniya v usloviyah vnedrenie sistemyie-Learning [Methods of organizing mobile learning in the context of e-Learning system implementation]", News KSTU. I.Razzakova. Tokmok-ITS "Technik" No. 1 (41) part 1 (2017): 205-209.

[21] Abdyldaev E.K. "Uchet vliyaniya strukturyi massiva pri opredelenii ustoychivosti otkosa karera [Accounting for the influence of the structure of the array in determining the stability of the slope of the pit]" , Bulletin of the Kyrgyz-Russian Slavic University. A series of natural and technical sciences. Bishkek Volume 17, Number 8 (2017): 65-67

[22] Abdyldaev E.K. "Napryazhenno-deformirovannoe sostoyanie massiva gornyih porod vblizi vyirabotok [The stress-strain state of the rock mass near the workings]", Frunze: Ilim (1990): 164.

[23] Abdyldaev E.K., Zhumazhanov B.ZH, Salimova, G.E. "Kriteriy otsenki ustoychivosti porodnogo massiva vblizi vyirabotok [Criterion for assessing the sustainability of the rock mass near the workings]" , Bulletin of the Al-Farabi Kazakh National University. Almaty 3 (54) (2007).

[24] Abdyldaev E.K. "Modeli otsenki napryazhennogo sostoyaniya massiva vblizi vyrabotok pri kombinirovannoy razrabotke [Models for estimating the stress state of the massif near the workings during combined mining]", Weeds abstracts of the International scientific - practical conference "Actual problems of computer science, mechanics and robotics. Digital technologies in mechanical engineering" Almaty (2018): 21-22

[25] Abdyldaev E.K., Orazayeva L., Uypalakova D.M. "Informatsionnaya tehnologiya pri chislennom reshenii prikladnyih zadach [Information technology in the numerical solution of applied problems]", The weed of materials from the International Scientific and Practical Conference "Modern Information and Communication Technologies in Education, Science and Practice" in the framework of the third modernization of Kazakhstan. Kazakh State Women's Pedagogical University, Almaty (2018): 3 . 